\title{
PENGARUH KESELAMATAN DAN KESEHATAN KERJA (K3) TERHADAP PRODUKTIVITAS KERJA KARYAWAN PADA PT. KUTAI TIMBER INDONESIA
}

(Studi Kasus Pada PT. Kutai Timber Indonesia Kota Probolinggo)

\author{
Nining Wahyuni ${ }^{1}$, Bambang Suyadi ${ }^{1}$, Wiwin Hartanto ${ }^{1}$ \\ ${ }^{1}$ Program Studi Pendidikan Ekonomi, Fakultas Keguruan dan Ilmu Pendidikan, Universitas Jember \\ e-mail: wiwinhartanto@unej.ac.id
}

\begin{abstract}
Abstrak
Keselamatan dan kesehatan kerja termasuk salah satu program pemeliharaan yang ada di perusahaan.Pelaksanaan program keselamatan dan kesehatan kerja bagi karyawan sangatlah penting karena bertujuan untuk menciptakan sistem keselamatan dan kesatuan kerja yang nantinya dapat meningkatkan produktivitas kerja karyawan.Tujuan penelitian ini yaitu untuk mengetahui apakah ada pengaruh keselamatan dan kesehatan kerja (K3) terhadap produktivitas kerja karyawan pada PT. Kutai Timber Indonesia Kota Probolinggo. Penelitian ini merupakan penelitian kuantitatif dengan menggunakan dua uji instrumen data yaitu uji validitas dan uji reliabilitas. Adapun metode analisis data yang digunakan yaitu analisis regresi linier sederhana, analisis varian garis regresi, uji $\mathrm{F}$, analisis koefisien determinasi dan standart error of estimate. Metode pengumpulan data yang digunakan adalah kuisioner, observasi, wawancara dan dokumen. Sampel dalam penelitian ini adalah karyawan PT. Kutai Timber Indonesia yang berjumlah 85 responden. Hasil penelitian ini menunjukkan bahwa "keselamatan dan kesehatan kerja (K3) berpengaruh signifikan terhadap produktivitas kerja karyawan pada PT. Kutai Timber Indonesia". Hal ini dapat dibuktikan dari nilai R-Square sebesar $67,9 \%$.
\end{abstract}

Kata Kunci: Keselamatan dan Kesehatan Kerja (K3), Produktivitas Kerja

\section{PENDAHULUAN}

Sumber daya manusia memegang peranan penting bagi keberhasilan suatu organisasi atau perusahaan, karena manusia merupakan aset hidup yang perlu diperhatikan secara khusus oleh perusahaan. Kenyataan bahwa manusia sebagai aset utama dalam organisasi atau perusahaan, harus mendapatkan perhatian serius dan dikelola dengan sebaik mungkin. Hal ini dimaksudkan agar sumber daya manusia yang dimiliki perusahaan mampu memberikan kontribusi yang optimal dalam upaya pencapaian tujuan organisasi.Dalam pengelolaan sumber daya manusia inilah diperlukan manajemen yang mampu mengelola sumber daya secara sistematis, terencana, dan efisien.

Terdapat berbagai sumber daya yang dibutuhkan dalam menjalankan suatu bisnis perusahaan, seperti modal, material dan mesin.Tidak terkecuali perusahaan juga membutuhkan sumber daya manusia, yaitu para karyawan.Karyawan yang diharapkan organisasi tentunya adalah karyawan yang dapat bekerja produktif, yaitu yang berkemampuan untuk menghasilkan produktivitas kerja yang optimal seperti yang direncanakan.

Produktivitas merupakan indikator utama bagi kemajuan sebuah perusahaan, sehingga peningkatan produktivitas pada semua bagian sistem merupakan suatu cara untuk meningkatkan laju pertumbuhan ekonomi perusahaan tersebut. Perusahaan berupaya untuk meningkatkan produktivitas seluruh karyawannya agar mampu bersaing dengan perusahaan lain karena dapat menghasilkan suatu barang atau jasa dengan cara yang lebih efisiensi.Selain produktivitas kerja karyawan, terdapat pula salah satu hal yang harus menjadi perhatian, yaitu keselamatan dan kesehatan kerja.Keselamatan dan kesehatan kerja termasuk salah satu program pemeliharaan yang ada di perusahaan.

Keselamatan kerja adalah keselamatan yang berhubungan dengan aktivitas kerja manusia baik pada industri, manufaktur dan kontruksi, yang melibatkan mesin, peralatan, penanganan material, pesawat uap, bejana bertekanan, alat kerja bahan baku dan proses pengolahannya, landasan tempat kerja dan lingkungannya serta cara-cara melakukan pekerjaan, maupun industri jasa, yang melibatkan peralatan pembersih gedung, sarana transportasi, dan lain-lain (Meggison dalam Mangkunegara, 2002:138).

Kesehatan kerja didalam perusahaan merupakan spesialisasi dalam ilmu kesehatan beserta prakteknya dengan mengadakan penilaian kepada faktor-faktor penyebab penyakit dalam lingkungan kerja dan perusahaan melalui pengukuran yang hasilnya dipergunakan untuk dasar tindakan korektif dan bila perlu pencegahan kepada 
lingkungan tersebut, agar pekerja dan masyarakat sekitar perusahaan terhindar dari bahaya akibat kerja, serta dimungkinkan untuk mengecap derajat kesehatan setinggi-tingginya (Kuswana : 2014).

Keselamatan dan Kesehatan Kerja (K3) ini sangat penting diterapkan khususnya pada perusahaan yang berhubungan langsung dengan bidang produksi agar karyawandapat merasa aman, nyaman, sehat dan selamat dalam melakukan pekerjaan mereka, sehingga produktivitas kerja dapat tercapai secara optimal. Dalam penelitian ini, yaitu Keselamatan dan Kesehatan Kerja (K3) telah di terapkan di PT. Kutai Timber Indonesia sejak awal berdirinya perusahaan KTI hingga saat ini. Program K3 yang diterapkan pada PT. Kutai Timber Indonesia antara lain: (a) Program tentang pelatihan evakuasi tanggap darurat; (b) Pelatihan penggunaan APAR (Alat Pemadam Api Ringan), yang mana pelatihan ini merupakan program perusahaan untuk melatih semua orang yang bekerja di PT. Kutai Timber Indonesia (PT. KTI) mengerti dan mengetahui cara penggunaannya; (c) Safety induction tentang Keselamatan dan Kesehatan Kerja (K3); (d) Program tentang SOP (Standard Operational Procedure); dan (e) Pengenalan tentangHIRAX, yaitu kegunaannya untuk mengidentifikasi bahaya dan resiko yang ada di tempat kerja.

Berdasarkan pernyataan di atas, tujuan penelitian ini yaitu untuk mengetahui pengaruh keselamatan dan kesehatan kerja terhadap produktivitas kerja karyawan pada PT. Kutai Timber Indonesia.

\section{METODE PENELITIAN}

Penelitian ini bertujuan untuk mengetahui pengaruh keselamatan dan kesehatan kerja terhadap produktivitas kerja karyawan pada PT. Kutai Timber Indonesia. Metode pengumpulan data dalam penelitian ini terdiri darikuisioner, observasi, wawancara dan dokumen. Adapun metode pengolahan data dalam penelitian ini yaitu terdiri dari editing, skoring dan tabulasi. Uji instrumen data yang digunakan dalam penelitian ini yaitu uji validitas dan uji reliabilitas. Metode analisis data yang digunakan dalam penelitian ini adalah analisis inferensial. Analisis ini merupakan analisis statistik dengan menggunakan persamaan regresi linear sederhana yang digunakan untuk menguji hipotesis yang diajukan oleh peneliti. Adapun langkah-langkah yang digunakan dalam analisis ini yaitu persamaan regresi linier sederhana, analisis varian garis regresi, uji $\mathrm{F}$, efektivitas garis regresi dan standart error of estimate.

Populasi dalam penelitian ini adalah seluruh karyawan PT. Kutai Timber Indonesia yang berada di bagian produksi PB (Particle Board) yakni sebanyak 398 responden. Sampel dalam penelitian ini ialah sebanyak 85 responden dengan teknik simple random sampling. Penentuan jumlah sampel dalam penelitian ini mengacu pada pendapat Bungin. Perhitungan besaran sampel sebagai berikut :

$$
\mathrm{n}=\frac{\mathrm{N}}{\mathrm{N}(\mathrm{d})^{2}+1}
$$

(Bungin, 2006:105)

Maka jumlah sampel yang digunakan dalam penelitian ini berdasarkan perhitungan diatas ialah sebanyak 85 responden.

\section{HASIL DAN PEMBAHASAN}

Sebagai perusahaan dengan standar internasional banyak sekali standar-standar yang harus dipenuhi.Pemenuhan standar ini bukanlah hanya suatu kewajiban namun merupakan suatu kebutuhan. Sistem Manajemen K3 OHSAS 18001:2007 adalah salah satu standar yang telah dipenuhi oleh PT. Kutai Timber Indonesia, di samping standar-standar internasional lainnya seperti sertifikasi ISO 9001:2000 pada bulan Januari 2004 dan ISO 14001 pada bulan Agustus 2001.

OHSAS 18001:2007 merupakan suatu standar untuk mengontrol risiko kesehatan dan keselamatan kerja dan meningkatkan kinerja kesehatan dan keselamatan kerja yang mempunyai sasaran untuk mencegah kecelakaan dan sakit. PT. Kutai Timber Indonesia telah menerapkan dan mendapat sertifikat OHSAS 18001:2007 sejak tahun 2013 sampai saat ini dari Sucofindo yang merupakan anggota ALSI (Asosiasi Lembaga Sertifikasi Indonesia). Seluruh pimpinan dan jajaran PT. Kutai Timber Indonesia sepakat untuk menerapkan Sistem Manajemen K3 berbasis OHSAS 18001:2007 di seluruh unit kerja khususnya pabrik produksi maupun proses distribusi produk disamping Manajemen Mutu. 
Penerapan keselamatan dan kesehatan kerja di PT. Kutai Timber Indonesia ialah sebagai berikut :

Pertama, PT. Kutai Timber Indonesia dalam meningkatkan produktivitaspekerja, pengetahuan, keterampilan dan kemampuan sesuai pekerjaannya dilakukan training yang terkait dengan aktivitas kerja secara berkesinambungan. Melatih pekerja dan memastikan kesadaran dan kompetensi pekerja di bidang K3, seperti pelatihan penggunaan alat pemadam api ringan (APAR) dan Hydrant, pelatihan jalur evakuasi (assembly point), material safety data sheet (MSDS), P3K, tata cara pembuangan sampah sesuai dengan karakteristiknya, pengenalan terhadap rambu-rambu lingkungan dan K3 yang ada di dalam lingkungan perusahaan dan lainlain.Pelatihan ini dilakukan sebanyak empat kali dalam satu tahun atau tiga bulan sekali yaitu periode I (januarimaret), periode II (april-juni), periode III (juli-september), dan periode IV (oktober-desember).Pelatihan ini di instrukturi oleh kepala divisi KL (Kerja Lingkungan).

Kedua, PT. Kutai Timber Indonesia dalam mengantisipasi dan meminimkan kecelakaan kerja, perusahaan memberikan alat pelindung kerja kepada setiap karyawan.Alat pelindung kerja yang telah disediakan oleh PT. Kutai Timber Indonesia diantaranya ialah : topi/helm, sepatu boots, sarung tangan dan masker yang dapat menghindarkan karyawan dari kecelakaan kerja. Ketiga, PT. Kutai Timber Indonesia menerapkan pelayanan antar-jemput karyawan, perusahaan ini telah menyediakan kendaraan berupa bus sebanyak delapan puluh bus untuk mengantar dan menjemput karyawan. Hal ini bertujuan untuk meningkatkan keselamatan karyawan, sehingga karyawan tidak perlu khawatir akan perjalanan berangkat dan pulang kerja.Keempat, PT. Kutai Timber Indonesia mengadakan olah raga bersama setiap hari jum'at pagi pukul 06.00 WIB-07.00 WIB, hal ini guna menunjang kesehatan setiap karyawan yang bekerja. Perusahaan ini juga memberikan konsumsi berupa makan dan minum pada setiap karyawan disaat jam istirahat.

Kelima, PT. Kutai Timber Indonesia menekankan pada lingkungan kerja. Lingkungan kerja yang baik dapat mempertinggi efisien dan efektifitas kerja karyawan. Adapun indikator-indikator keadaan lingkungan kerja yang diperhatikan di PT. Kutai Timber Indonesia, ialah sebagai berikut: i) Penerangan, di tempat kerja PT. Kutai Timber Indonesia yang baik, mampu memberikan kenyamanan bagi karyawan, setiap ruangan divisi disediakan sebanyak dua puluh lampu, dan juga warna ruang kantor yang serasi sehingga dapat meningkatkan produksi dan semangat kerja karyawan; ii) Sirkulasi udara, di tempat kerja PT. Kutai Timber Indonesia sangat baik, karena ruangan kerja tidak berdebu dan tidak lembab.Temperatur yang tidak terlalu panas atau terlalu dingin sehingga dapat meningkatkan kenyamanan dan semangat kerja karyawan. Keenam, PT. Kutai Timber Indonesia khususya divisi KL (Kerja Lingkungan) menerapkan jadwal piket kebersihan yang dilaksanakan setiap satu minggu satu kali yaitu setiap hari Sabtu dan dilakukan oleh setiap anggota divisi KL.

Uji instrumen dalam penelitian ini yakni terdapat dua pengujian, diantaranya adalah uji validitas dan uji reliabilitas. Sedangkan analisis data yang digunakan diantaranya ialah analisis regresi sederhana, analisis varian garis regresi, uji F, analisis koefisien determinasi, dan standart error of estimate. Adapun hasil pengujian dari uji instrumen dan analisis data tersebut ialah sebagai berikut:

(a) Uji Validitas, pengujian validitas yang digunakan dalam penelitian ini adalah korelasi Product Moment dan di anggap valid jika nilai $r \geq 0.30$ maka instrumen tersebut dapat dikatakan valid dan apabila nilai $r \leq 0,30$ maka instrumen tersebut dikatakan tidak valid atau jika $\mathrm{P} \leq 0,05$ maka pertanyaan tersebut dapat dikatakan valid dan apabila $\mathrm{P} \geq 0,05$ maka pertanyaan tersebut dapat dikatakan tidak valid; (b) Uji Reliabilitas, pengujian yang dilakukan dalam uji reliabilitas ini adalah metode Cronbach's Alpha. Pada uji reliabilitas akan menunjukkan hubungan antara jumlah butir pertanyaan dengan reliabilitas instrument. Dengan melakukan perbandingan antara angka kritis dan tabel alpha.Hasil uji reliabilitas dinyatakan reliabel jika hasil perhitungan memiliki koefisien keandalan (reliabilitas) sebesar $\alpha \geq 0,60$. Nilai Cronbach's Alpha dari angket keselamatan dan kesehatan kerja yaitu sebesar 0,861 dan nilai Cronbach's Alpha dari kuesioner produktivitas kerja karyawan yaitu sebesar 0,851 yang lebih besar dari angka kritis, artinya hasil kuesioner tersebut reliabel. Hal ini membuktikan hasil penelitian cukup dapat dipercaya dan sesuai dengan kenyataannya, dan hasilnya tetap sama meskipun angket disebarkan sebanyak dua kali kepada responden.

Analisis data penelitian ini menggunakan analisis regresi sederhana.Analisis garis regresi sederhana digunakan utuk mengetahui pengaruh antara variabel Keselamatan dan Kesehatan Kerja (X) terhadap Produktivitas Kerja Karyawan (Y). Pada penelitian ini, dilakukan analisis garis regresi sederhana dengan menggunakan program SPSS. Hasil analisis disajikan pada tabel berikut ini: 
Tabel 1. Hasil Analisis Regresi Linier Sederhana

\begin{tabular}{|c|c|c|c|c|c|}
\hline \multirow[t]{2}{*}{ Model } & \multicolumn{2}{|c|}{$\begin{array}{l}\text { Unstandardized } \\
\text { Coefficients }\end{array}$} & \multirow{2}{*}{$\begin{array}{c}\text { Standardized } \\
\text { Coefficients }\end{array}$} & \multirow[t]{2}{*}{$\mathrm{T}$} & \multirow[t]{2}{*}{ Sig } \\
\hline & B & Std. Error & & & \\
\hline (Constant) & 1,246 & 1,478 & & ,843 & ,402 \\
\hline $\begin{array}{l}\text { Keselamatan dan kesehatan } \\
\text { kerja (K3) }\end{array}$ & ,228 & ,031 & 679 & 7,37 & ,000 \\
\hline
\end{tabular}

Sumber: Hasil Regresi SPSS Versi 20

Berdasarkan Tabel 1 maka persamaan regresi linier sederhana yang didapatkan sebagai berikut:

$$
\hat{\mathrm{Y}}=1,246+0,228 \mathrm{X}+\mathrm{ei}
$$

Nilai konstanta dari persamaan tersebut adalah 1,246.Nilai konstanta menunjukkan nilai positif sebesar 1,246 artinya apabila nilai keselamatan dan kesehatan kerja (X) dan ei nilainya konstan (nol), maka nilai produktivitas kerja (Y) sebesar 1,246.

Besarnya nilai koefisien regresi keselamatan dan kesehatan kerja adalah 0,228, artinya apabila variabel (X) keselamatan dan kesehatan kerja mengalami kenaikan sebesar 1 satuan, maka produktivitas kerja (Y) akan mengalami peningkatan sebesar 0,228 satuan.

Analisis varian garis regresi digunakan untuk mengetahui kuat tidaknya atau untuk mengetahui tingkat keeratan komponen variabel keselamatan dan kesehatan kerja (X) terhadap produktivitas kerja karyawan (Y). Adapun besarnya varian garis regresi antara variabel keselamatan dan kesehatan kerja (X)dan variabel produktivitas kerja karyawan (Y) dapat dilihat pada Tabel 2 sebagai berikut:

Tabel 2. Koefisien korelasi keselamatan dan kesehatan kerja terhadap produktifitas kerja karyawan

\begin{tabular}{|l|c|}
\hline Variabel & R \\
\hline Keselamatan dan Kesehatan Kerja (X) & 0,679 \\
\hline Dependen Variabel: Y & \\
\hline
\end{tabular}

Sumber : Olahan SPSS Versi 20

Berdasarkan perhitungan tersebut dapat diketahui bahwa nilai koefisisen korelasi sebesar 0,679 berarti bahwa keselamatan dan kesehatan kerja (X) memiliki hubungan yang nyata dengan produktivitas kerja karyawan (Y).Tabel 2 menunjukkan interpretasi terhadap koefisien korelasi bisa terlihat sebagai berikut yang digunakan sebagai interpretasi terhadap koefisien korelasi. Tingkat hubungan antara variabel keselamatan dan kesehatan kerja dengan variabel produktivitas tenaga kerja dapat dikategorikan sebagai hubungan yang kuat.

Pengujian hipotesis penelitian ini digunakan untuk mengetahui tingkat signifikan keselamatan dan kesehatan kerja berpengaruh pada produktivitas kerja karyawan PT. Kutai Timber Indonesia dapat dilihat pada Tabel 3. Tabel 3 dapat diketahui bahwa $F$ hitung sebesar 54,425 dan besarnya $F$ tabel dengan taraf signifikansi 0,000 adalah 3,93. Dengan kriteria pengujian sebagai berikut:

a. Ho diterima, jika F hit $<\mathrm{F}$ tabel atau Sig $>\alpha$, variabel keselamatan dan kesehatan kerja tidak berpengaruh terhadap produktivitas kerja karyawan.

b. Ha diterima, jika F hit $\geq \mathrm{F}$ tabel atau $\mathrm{Sig}<\alpha$, variabel keselamatan dan kesehatan kerja berpengaruh terhadap produktivitas kerja karyawan. 
Tabel 3. Hasil Uji F

\begin{tabular}{|c|c|c|c|c|}
\hline Variabel & F hitung & F tabel & A & Sig. F \\
\hline $\mathrm{X}$ & 54,425 & 3,93 & 0,05 & 0,000 \\
\hline Dependen Variabel $=\mathrm{Y}$ & & & \\
\hline
\end{tabular}

Sumber : Olahan SPSS Versi 20

Penelitian ini menunjukkan F hitung sebesar 54,425 > F tabel sebesar 3,93 atau signifikan sebesar 0,000 $<\alpha$ sebesar 0,05, maka dapat disimpulkan bahwa variabel keselamatan dan kesehatan kerja berpengaruh signifikan terhadap variabel produktivitas kerja karyawan. Berdasarkan data tersebut pengujian hipotesis penelitian ini dapat dikatakan bahwa "keselamatan dan kesehatan kerja berpengaruh signifikan terhadap produktivitas kerja karyawan pada PT. Kutai Timber Indonesia”.

Koefisien determinasi digunakan untuk mengukur besarnya proporsi sumbangan variabel bebas (X) terhadap variabel terikat (Y). Dalam penelitian ini hasil analisis diperoleh nilai koefisien determinasi (Rsquare)sebesar 0,679 .

R-square $\times 100 \%=0,679 \times 100 \%=67,9 \%$

Hal ini menunjukkan bahwa besarnya persentase pengaruh variabel keselamatan dan kesehatan kerja terhadap produktivitas kerja karyawan sebesar $67,9 \%$, sedangkan sisanya $32,1 \%$ dipengaruhi variabel bebas lainnya yang tidak diteliti dalam penelitian ini, seperti produktivitas kerja yang dipengaruhi oleh variabel sikap mental, sarana produksi dan kesempatan berprestasi.

Standart Error of Estimate digunakan untuk mengukur variasi nilai $\mathrm{Y}$ actual dari garis regresinya sehingga akan diketahui tingkat representatif garis regresinya. Hasil pengolahan data bagian dari model summary menunjukkan bahwa nilai Standart Error of Estimate dalam analisis garis linier sederhana sebesar 1,98391. Hal tersebut menunjukkan bahwa variasi nilai Y actual dari garis regresinya adalah sebesar 1,98391. Besarnya Standart Error of Estimate sebesar 1,98391 menunjukkan besarnya penyimpangan variabel produktivitas kerja karyawan terhadap garis regresinya.

Secara keseluruhan hasil analisis menunjukan bahwa pengaruh variabel bebas atau independent yaitu variabel keselamatan dan kesehatan kerja berpengaruh secara signifikan terhadap variabel terikat yaitu produktivitas kerja karyawan PT. Kutai Timber Indonesia.Hal tersebut berarti kebijakan manajemen untuk menjalankan program keselamatan dan kesehatan kerja berdasarkan aturan yang berlaku. Berdasarkan hasil penelitian yang dilakukan untuk melihat pengaruh variabel keselamatan dan kesehatan kerja (K3) terhadap variabel produktivitas kerja karyawan, diketahui bahwa R-Square sebesar 67,9\%. Hal tersebut menunjukkan bahwa perusahaan telah memberikan fasilitas berupa keselamatan dan kesehatan kerja (K3) karyawan agar merasa aman bekerja serta dapat mengurangi resiko kecelakaan kerja serta meningkatnya kenyamanan lingkungan bekerja sehingga karyawan merasa dilindungi saat kerja.

Perusahaan harus mengerti bahwa keselamatan kerja yang baik adalah dengan memberikan karyawan alat pelindung diri, memperhatikan kondisi alat kerja, melakukan perawatan alat, menyediakan bahan baku yang baik, memberikan penerangan/pencahayaan yang baik di lokasi kerja, serta kebersihan dan ketertiban yang terjaga. Jika perusahaan dapat memenuhi hal-hal tersebut maka karyawan akan bekerja dengan lebih nyaman tanpa ada rasa khawatir akan terjadi kecelakaan kerja, sehingga karyawan lebih produktif lagi dalam bekerja.

PT. Kutai Timber Indonesia telah menyiapkan fasilitas-fasilitas yang diperlukan karyawannya dalam bekerja, seperti Alat Pelindung Diri (APD) untuk memberikan jaminan keselamatan kepada karyawan. Karyawan PT. Kutai Timber Indonesia menguasai prosedur kerja dan cara kerja yang ditetapkan diperusahaan. Terbukti dari kuesioner X1 yang menyatakan tentang cara penggunaan alat kerja, dimana rata-rata jawaban responden sebesar 4 yang artinya setuju dan ini menunjukkan bahwa perusahaan telah menyediakan alat pelindung diri berupa topi/helm, masker, sepatu boots, dan lain sebagainya. Sehingga walaupun yang dikejar adalah target produksi dapat waspada akan terjadinya kecelakaan kerja.

Berdasarkan data hasil penelitian yang di peroleh bahwa keselamatan dan kesehatan kerja di PT. Kutai Timber Indonesia harus diperbaiki dalam hal pemberian solusi bagi karyawan yang memperoleh kesulitan pekerjaan. Hal ini dapat dilihat dari tanggapan responden terhadap perusahaaan yang dapat terbukti dari kuisioner X5 yaitu memberikan solusi kerja bagi karyawan yang memperoleh kesulitan pekerjaan, rata-rata jawaban responden sebesar 4 yang berarti setujudan menunjukkan bahwa karyawan PT. Kutai Timber Indonesia setuju dalam pemberian solusi kerja bagi karyawan yang kesulitan dalam melakukan pekerjaannya. Pekerjaan 
yang dilakukan di PT. Timber Kutai Indonesi merupakan pekerjaan yang berbahaya karena berkaitan dengan alat-alat berat, oleh karena itu perlu ditingkatkan lagi pelatihan mengenai pekerjaan masing-masing karyawan sehingga dapat meminimalisir terjadi kecelakaan kerja.

\section{KESIMPULAN DAN SARAN}

Berdasarkan hasil analisis data dan pembahasan mengenai Pengaruh Keselamatan dan Kesehatan Kerja Terhadap Produktivitas Kerja Karyawan dapat disimpulkan bahwa variabel keselamatan dan kesehatan kerja memiliki pengaruh yang signifikan terhadap produktivitas kerja karyawan.Hal itu dapat dilihat dari nilai R-square sebesar $67,9 \%$.

Berdasarkan kesimpulan yang telah didapat dari penelitian ini, maka dapat dikemukakan beberapa saran dari peneliti sebagai berikut:

Bagi Perusahaan : Perusahaan harus mempertahankan kebijakan pengurangan resiko kecelakaan kerja melalui berbagai program K3 karena memberikan kontribusi positif bagi peningkatan produktivitas kerja karyawan pada PT. Kutai Timber Indonesia.

Bagi Karyawan : Karyawan diharapkan selalu menggunakan Alat Pelindung Diri (APD) saat bekerja agar dapat mengurangi resiko kecelakaan kerja dan mematuhi petunjuk tentang penggunaan alat kerja yang benar agar dapat meningkatkan produktivitas kerja.

\section{DAFTAR PUSTAKA}

Bungin, B. 2006.Metodologi Penelitian Kuantitatif. Jakarta: Kencana.

Kuswana, W. S. 2014. Ergonomi dan K3 Kesehatan Keselamatan Kerja. Bandung: PT. Remaja Rosdakarya.

Mangkunegara, A.A. Anwar Prabu. 2002. Manajemen Sumber Daya Manusia Perusahaan. Bandung: PT.

Remaja Rosdakarya.

Sugiyono. 2011. Metode Penelitian Kuantitatif, Kualitatif dan R\&D. Bandung: Pustaka Grafika

Sugiyono. 2014. Metode Penelitian Kuantitatif, Kualitatif dan R\&D. Bandung: Alfabeta. 